\title{
Concentration Dependence of 'Redchief Delicious' Apple Fruit Softening and Chlorophyll Fluorescence to Repeated Doses of 1-Methylcyclopropene
}

\author{
Sastry S. Jayanty ${ }^{1}$, Mauricio Cañoles ${ }^{2}$, and Randolph M. Beaudry ${ }^{3}$ \\ Postharvest Technology and Physiology Laboratory, Department of Horticulture, Michigan State \\ University, East Lansing, MI 48824
}

\begin{abstract}
AdDitional INDEX WORDs. texture, firmness, ripening, storage, temperature
Abstract. We studied the dose-response of 'Redchief Delicious' apple [Malus sylvestris (L) Mill. var. domestica (Borkh.) Mansf.] fruit to repeated (weekly) dosages of $0.0,0.02,0.1$, and $1.0 \mu \mathrm{L} \cdot \mathrm{L}^{-1} 1$-methylcyclopropene (1-MCP) by measuring fruit firmness and chlorophyll fluorescence throughout an extended storage period at $0,5,10,15$, and $20^{\circ} \mathrm{C}$. The rate of firmness loss for nontreated fruit increased with increasing temperature. 1-MCP applied at concentrations of 0.1 and $1.0 \mu \mathrm{L} \cdot \mathrm{L}^{-1}$ slowed firmness loss. The 1-MCP dose-response curve for the rate of firmness loss was essentially the same for all five temperatures. A concentration of $1.0 \mu \mathrm{L} \cdot \mathrm{L}^{-1} 1-\mathrm{MCP}$ prevented firmness loss at all temperatures for the duration of the study; however, after holding fruit for an additional 7 days at room temperature, the fruit stored at $10{ }^{\circ} \mathrm{C}$ softened with increasing storage duration, whereas fruit at stored at higher and lower temperatures did not. The influence of 1-MCP on chlorophyll fluorescence (Fo and Fm) was markedly affected by temperature; Fo increased during storage at higher storage temperatures and this increase was enhanced by 1-MCP. Conversely, Fm decreased during storage and the rate of decline was much greater at the higher storage temperatures; the rate of decline was reduced by 1-MCP, but only at the higher storage temperatures. Photochemical efficiency $(\mathrm{Fv} / \mathrm{Fm})$ of nontreated fruit declined with time for all storage temperatures. Treatment with 0.1 and $1.0 \mu \mathrm{L} \cdot \mathrm{L}^{-1} 1-\mathrm{MCP}$ only marginally reduced the rate of decline of photochemical efficiency. Sample loss due to decay increased with temperature, but was reduced by 1-MCP at all temperatures.
\end{abstract}

1-Methylcyclopropene (1-MCP) inhibits ethylene action and can improve the storability of horticultural commodities for which ethylene plays a role in ripening, abscission, or senescence (Abdi et al., 1998; Fan et al., 1999a; Golding et al., 1998; Ku and Wills 1999; Porat et al., 1999; Sisler and Blankenship, 1996; Sisler et al., 1996; Sisler and Serek, 1997). 1-MCP was approved by the U.S. Environmental Protection Agency (EPA) for application to edible crops on 26 July 2002 (EPA, 2002) and currently is labeled by its manufacturer for use on apple fruit. 1-MCP effectively slows changes in the texture of apple fruit associated with ripening (Dauny and Joyce, 2002; Fan et al., 1999a; Mir et al., 2001; Watkins et al., 2000). Apart from negating ethylene effects during ripening, Fan et al. (1999b) and Rupasinghe et al. (2000) showed that 1-MCP application also reduced physiological disorders such as superficial scald, soft scald, core flush, and greasiness in different apple cultivars during storage.

The published data for dose-response of apple to 1-MCP are predominantly derived from studies using single applications of $1-\mathrm{MCP}$ at various temperatures for various durations. Watkins et al. (2000) used three different 1-MCP concentrations $(0.5,1.0$, and $\left.2.0 \mu \mathrm{L} \cdot \mathrm{L}^{-1}\right)$ at temperatures between 20 and $25^{\circ} \mathrm{C}$ for $7 \mathrm{~h}$ duration. DeEll et al. (2002) tested the influence of three different temperature regimes $\left(3,13\right.$, and $\left.23^{\circ} \mathrm{C}\right)$ in combination with eight different durations of exposure to $0.6 \mu \mathrm{L} \cdot \mathrm{L}^{-1} 1$-MCP. Dauny

Received for publication 14 Oct. 2003. Accepted for publication 11 Feb. 2004. We thank Erin Curell, Melissa Butkiewicz, and Najma Khan for their expert technical services. Research supported by the Project for Generating Research and Extension to meet Economic and Environmental Needs (GREEEN) at MSU. Use of trade names does not imply endorsement of the products named or criticism of similar ones not named.

'Postdoctoral Research Associate.

${ }^{2}$ Doctoral Student.

${ }^{3}$ Professor, to whom reprint requests should be addressed; e-mail address: beaudry@msu.edu. and Joyce (2002) reported on three separate experiments evaluating the influence of $1-\mathrm{MCP}$ concentration $\left(0.1\right.$ to $\left.10.0 \mu \mathrm{L} \cdot \mathrm{L}^{-1}\right)$, exposure duration (6 to $48 \mathrm{~h})$, and treatment temperature $(0,5$, 10,15 , and $20^{\circ} \mathrm{C}$ ) on firmness retention by 'Queen Cox' and 'Bramley' apple fruit stored in air at 3 to $4{ }^{\circ} \mathrm{C}$ for 2 or 3 months. Lurie et al. (2002) compared apple volatile emission with respect to $1-\mathrm{MCP}$ concentration. The treatments were 0.1 and $1.0 \mu \mathrm{L} \cdot \mathrm{L}^{-1}$ $1-\mathrm{MCP}$ at $20^{\circ} \mathrm{C}$ for $20 \mathrm{~h}$. Collectively, the data for single doses suggest that a maximal response is dependent on the exposure concentration, duration, temperature, and cultivar. Dose-response curves indicate that between 0.5 and $1 \mu \mathrm{L} \cdot \mathrm{L}^{-1} 1-\mathrm{MCP}$ is required for maximal response and an exposure duration of 3 to $6 \mathrm{~h}$ is needed at room temperature, depending on cultivar, whereas a 6- to 12-h exposure is needed at $3{ }^{\circ} \mathrm{C}$. The half-maximal response can be obtained by a dose of $\approx 0.05$ to $0.1 \mu \mathrm{L} \cdot \mathrm{L}^{-1}$. Although there have been no published reports on the influence of temperature on the dose-response of apple to single applications of 1-MCP, concentrations of 1-MCP that elicit a full response from apple are effective at temperatures from 0 to $25^{\circ} \mathrm{C}$.

Multiple and continuous doses of 1-MCP can provide benefits beyond those obtained by single doses (Mir and Beaudry, 2001; Mir et al., 2001, 2003). A single initial exposure of apple fruit to $0.7 \mu \mathrm{L} \cdot \mathrm{L}^{-1} 1-\mathrm{MCP}$ resulted in an $\approx 2$-fold increase in the time required for firmness to fall to a threshold level at $0,5,10,15$, and $20^{\circ} \mathrm{C}$. Multiple (weekly) doses of 1-MCP improved firmness retention relative to a single exposure at $5,10,15$, and $20^{\circ} \mathrm{C}$, but not $0{ }^{\circ} \mathrm{C}$. Furthermore, the time needed to soften to a threshold firmness level increased as temperature increased for those fruit receiving weekly applications (Mir and Beaudry, 2001). The improvement in firmness retention obtained by multiple 1-MCP applications at elevated temperatures suggests that new ethylene receptors produced after the initial 1-MCPexposure were occupied by 1-MCP molecules from subsequent doses as reported in some 
ornamentals (Blankenship and Dole, 2003; Cameron and Reid, 2001; Serek et al., 1994). The lack of a benefit from multiple doses at $0{ }^{\circ} \mathrm{C}$ suggested that turnover of the binding site was very limited at this temperature. Thus, it appears that temperature may impact ethylene biology sufficiently in apple that it differentially affects responses to single and multiple doses.

We wanted to determine if the dose-response of apple to 1MCP changed with temperature for fruit receiving multiple doses. We applied 1-MCP once per week at $0,5,10,15$, and $20{ }^{\circ} \mathrm{C}$ at concentrations of $0.0,0.02,0.1$, and $1.0 \mu \mathrm{L} \cdot \mathrm{L}^{-1}$ while holding the fruit in air.

\section{Materials and Methods}

Plant material. 'Redchief Delicious' apples were harvested from Michigan State University's Clarksville Horticulture Experimental Station, Clarksville, Mich. at an early climacteric stage as judged by the starch index and internal ethylene concentration (IEC) of 10 representative fruit. The average IEC was $0.11 \mu \mathrm{L} \cdot \mathrm{L}^{-1}$ (90\% having an IEC $<0.2 \mu \mathrm{L} \cdot \mathrm{L}^{-1}$ ) and the average starch index was 4.1. At the time of harvest, fruit had a firmness of $\approx 71$ to 73 $\mathrm{N}$. A total of 125 fruit having a diameter $>5.7 \mathrm{~cm}$ and free from obvious defects were randomly selected and placed in each of 50 plastic mesh bags. One such bag was placed in each of fifty $120-\mathrm{L}$ plastic barrels. After placing fruit in the barrels, 10 barrels were placed in each of five controlled environment chambers held at $0,5,10,15$, or $20^{\circ} \mathrm{C}$. Fruit temperature was allowed to equilibrate with the chambers's temperature by holding the barrels overnight with lids removed. Initial 1-MCP treatment took place on the 2nd day of the study.

1-MCP TREATMENT. Barrels were sealed by attaching the airtight lids. 1-MCP was administered by injection of a stock gas through septa into the barrel headspace. Treatment with 1-MCP took place weekly at the indicated storage temperatures; exposure duration was $16 \mathrm{~h}$. Target concentrations were 0.0, 0.01, 0.02, 0.1 , and $1.0 \mu \mathrm{L} \cdot \mathrm{L}^{-1} 1-\mathrm{MCP}$ at each temperature. The $0.01 \mu \mathrm{L} \cdot \mathrm{L}^{-1}$ 1-MCP concentration was below the limits of detectability of the GC used so the fruit analyses for this treatment were not included in this report. Barrels were sealed only when 1-MCP was applied. Between 1-MCPexposures, the barrels were continuously flushed with humidified air at the rate of $200 \mathrm{~mL} \cdot \mathrm{min}^{-1}$. There were two replicate barrels for each temperature/concentration treatment combination.

A concentrated 1-MCP stock gas was prepared each week in a $1-\mathrm{L}$ glass container by mixing $36.4 \mathrm{~g}$ of EthylBlock ${ }^{\circledR}$ (Biotechnologies for Horticulture, Philadelphia) with water using the technique of Mir et al. (2001). After allowing $2 \mathrm{~h}$ for the 1-MCP gas to evolve, concentrated 1-MCP gas from the jar headspace was injected into the barrels. Different concentrations were created by altering the quantity of 1-MCP stock gas injected. 1-MCP concentrations in the barrels were measured for three representative barrels for different 1-MCP concentrations. We found that the actual concentration of 1-MCP was less than anticipated based on the amount of EthylBloc ${ }^{\circ}$, possibly due to polymerization of the $1-\mathrm{MCP}$ molecules at the high concentrations present in the stock gas. The values given here are actual 1-MCP gas concentration measured in the barrels for each treatment.

Ethylene and 1-MCP concentrations were measured using gas chromatography (Carl Series 100 AGC) as reported previously (Mir et al., 2001). A standard for quantifying 1-MCP was prepared using $1.00 \mu \mathrm{L}^{\cdot} \mathrm{L}^{-1} 1$-butene (Matheson Gas Products, Chicago).
Quality evaluations. Ten fruit samples comprised of five fruit from each of the two replicates were removed at varying intervals and were analyzed for firmness and chlorophyll fluorescence on 1 and $7 \mathrm{~d}$ after removal from storage. Firmness and chlorophyll fluorescence were measured as described previously (Mir et al., 2001). The initial rate of firmness loss in storage was determined by fitting the most linear portion of the firmness data when regressed against storage duration; the first six to nine data points were used. Minimal (Fo) and maximal (Fm) chlorophyll fluorescence data were collected. Photochemical quantum efficiency was calculated from the ratio of (Fm-Fo)/Fm. The study continued until fruit supplies were exhausted.

Fruit losses due to decay were tabulated on storage samples from which fruit were drawn for quality analysis. Decayed fruit were removed from the storage containers when detected. An estimate of the rate of decay was obtained by dividing the number of decayed fruit in each storage chamber by the number of days required to exhaust the supply of 125 fruit.

\section{Results}

The firmness of nontreated 'Redchief Delicious' apple fruit after $1 \mathrm{~d}$ at $20^{\circ} \mathrm{C}$ post-storage declined as storage duration increased (Fig. 1). However, the firmness decline appeared to halt after 100 to $150 \mathrm{~d}$ of storage and firmness remained relatively constant thereafter at a minimum level that was temperature-dependent. Minimum firmness levels for $0,5,10,15$, and $20^{\circ} \mathrm{C}$ were $\approx 58,40$, 35,31 , and $31 \mathrm{~N}$, respectively. The firmness of fruit at minimal softness was not affected by holding them for an additional $6 \mathrm{~d}$ at $20^{\circ} \mathrm{C}$ (data not shown).

Fruit firmness did not differ between nontreated fruit and those treated with $0.02 \mu \mathrm{L} \cdot \mathrm{L}^{-1} 1-\mathrm{MCP}$ at any temperature after $1 \mathrm{~d}$ (Fig. 1) or $7 \mathrm{~d}$ post-storage (data not shown). Treatment of fruit with 0.1 or $1.0 \mu \mathrm{L} \cdot \mathrm{L}^{-1} 1-\mathrm{MCP}$ substantially slowed or arrested fruit softening, respectively. Nontreated fruit were softer than those receiving $1.0 \mu \mathrm{L} \cdot \mathrm{L}^{-1} 1-\mathrm{MCP}$ after $\approx 110,70,30,21$, and $15 \mathrm{~d}$ for fruit stored at $0,5,10,15$, and $20^{\circ} \mathrm{C}$, respectively.

As the storage temperature increased, the maximum rate of softening increased similarly for nontreated controls and fruit treated with $0.02 \mu \mathrm{L} \cdot \mathrm{L}^{-1}$ (Fig. 2). There was a slight increase in softening rate with temperature for fruit treated with $0.1 \mu \mathrm{L} \cdot \mathrm{L}^{-1}$ 1-MCP, but no relationship between storage temperature and softening rate was apparent for fruit treated with $1 \mu \mathrm{L} \cdot \mathrm{L}^{-1} 1-\mathrm{MCP}$. Of the fruit treated with $1.0 \mu \mathrm{L} \cdot \mathrm{L}^{-1} 1-\mathrm{MCP}$, only those held at 10 ${ }^{\circ} \mathrm{C}$ softened substantially over the course of the study (Figs. 1 and 2). At $20^{\circ} \mathrm{C}$, apples repeatedly treated with $1 \mu \mathrm{L} \cdot \mathrm{L}^{-1}$ maintained firmness at harvest levels of $\approx 73 \mathrm{~N}$ for $180 \mathrm{~d}$.

There was significant loss of fruit at higher temperature due to decay (Table 1). Loss to decay was greater for nontreated fruit and fruit treated with $0.02 \mu \mathrm{L} \cdot \mathrm{L}^{-1} 1-\mathrm{MCP}$ than for fruit treated with 0.1 and $1.0 \mu \mathrm{L} \cdot \mathrm{L}^{-1} 1-\mathrm{MCP}$. Removal of fruit for quality analysis will have resulted in an underestimate of actual decay rates, but since the number of sampling dates was between 9 and 14 for all treatment combinations, roughly similar numbers of fruit were removed by sampling.

Chlorophyll fluorescence values for Fo, Fm, and Fv/Fm were affected by 1-MCP, temperature, and storage duration for fruit held 1 and $7 \mathrm{~d}$ following storage. For nontreated fruit, Fo tended to remain unchanged at the lower temperatures and increased somewhat at elevated temperatures as storage duration increased (Fig. 3). This trend was more pronounced after an additional $7 \mathrm{~d}$ 


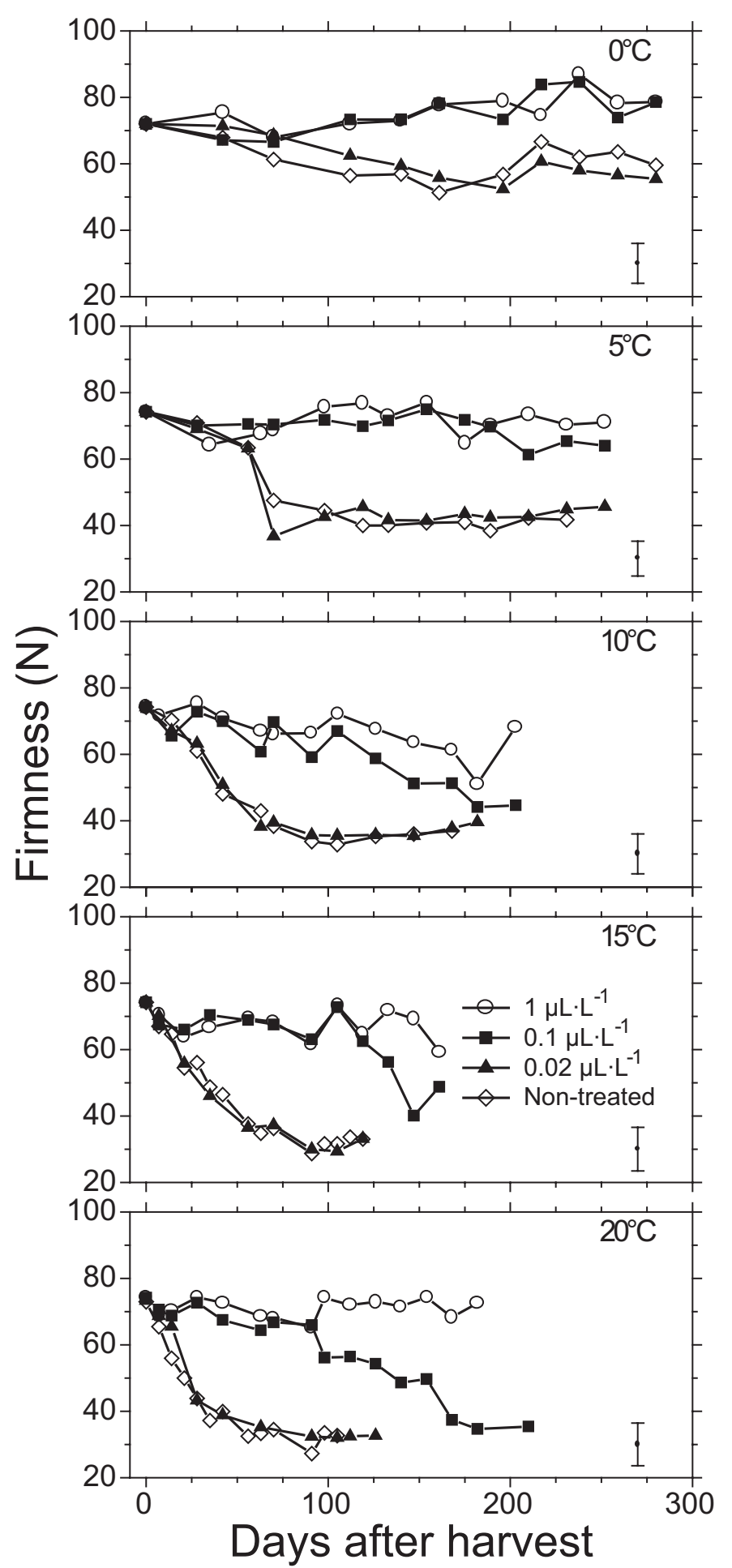

Fig. 1. Effect of 1-MCP on firmness of 'Redchief Delicious' apple fruit following storage in air at $20,15,10,5$, or $0{ }^{\circ} \mathrm{C}$. Treated fruit were exposed to 1.00 , 0.10 , and $0.02 \mu \mathrm{L} \cdot \mathrm{L}^{-1} 1-\mathrm{MCP}$ at the storage temperature for $16 \mathrm{~h}$ every week. Firmness measurements were made after holding fruit for an additional $24 \mathrm{~h}$ at $20^{\circ} \mathrm{C}$. Bars are \pm the average SD for all samples of the given temperature; $\mathrm{n}$ $=10$ fruit, five from each of two replicates.

post-storage holding (data not shown). The 0.1 and $1.0 \mu \mathrm{L} \cdot \mathrm{L}^{-1}$ treatments with 1-MCPdid not affect Fo at 0 and $5^{\circ} \mathrm{C}$, but resulted in a marked increase in this parameter relative to nontreatment at 15 and $20^{\circ} \mathrm{C}$ (Fig. 3). Unlike Fo, Fm declined as storage duration increased for all storage temperatures and 1-MCP treatments (Fig. 4). The rate of decline increased as storage temperature

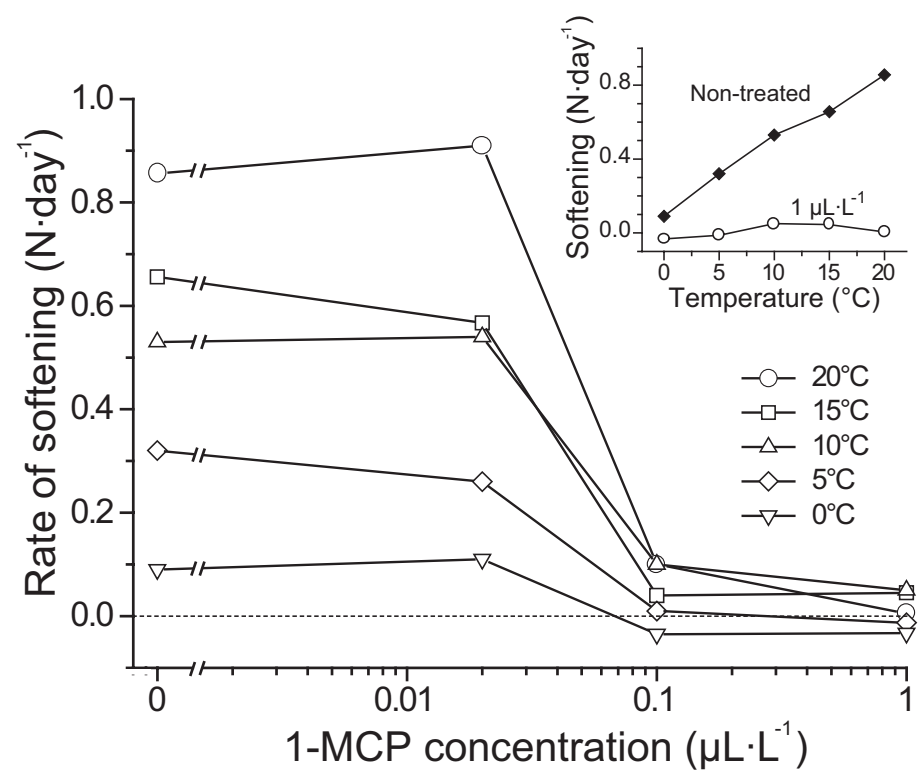

Fig. 2. Rate of softening of 1-MCP-treated 'Redchief Delicious' apple fruit at different temperatures as a function of 1-MCP concentration. Rate of softening was calculated for fruit during storage in air at $20,15,10,5$, or $0^{\circ} \mathrm{C}$. Treated fruit were exposed to $1.00,0.10$, and $0.02 \mu \mathrm{L} \cdot \mathrm{L}^{-1} 1-\mathrm{MCP}$ at the storage temperature for $16 \mathrm{~h}$ every week. Inset: Temperature-dependence of the rate of softening for fruit treated with $1 \mu \mathrm{L} \cdot \mathrm{L}^{-1} 1-\mathrm{MCP}$ and nontreated fruit.

Table 1. Effect of 1-MCP concentration and storage temperature on the daily rate of loss of 'Redchief Delicious' apple fruit due to decay. Decay rate was determined for two replicate lots of 125 fruit at each storage temperature/1-MCP combination from which fruit also were drawn for firmness and fluorescence analysis, therefore, rates reported here are underestimate of the actual rate.

\begin{tabular}{lccccc}
\hline 1-MCP concn & \multicolumn{5}{c}{ Temp $\left({ }^{\circ} \mathrm{C}\right)$} \\
\cline { 2 - 6 }$\left(\mu \mathrm{L} \cdot \mathrm{L}^{-1}\right)$ & 0 & 5 & 10 & 15 & 20 \\
\hline \multirow{5}{*}{0} & 0.034 & 0.085 & 0.15 & 0.13 & 0.53 \\
0.02 & 0.031 & 0.054 & 0.26 & 0.39 & 0.48 \\
0.10 & 0.014 & 0.022 & 0.085 & 0.11 & 0.20 \\
1.00 & 0.015 & 0.016 & 0.083 & 0.12 & 0.24 \\
\hline
\end{tabular}

increased; however, the decline rate was reduced by 0.1 and 1.0 $\mu \mathrm{L} \cdot \mathrm{L}^{-1} 1-\mathrm{MCP}$ at 15 and $20^{\circ} \mathrm{C}$. The measure of photochemical quantum efficiency, $\mathrm{Fv} / \mathrm{Fm}$, declined as storage duration increased for all temperatures and 1-MCP treatments (Fig. 5). The higher concentrations of 1-MCP provided some marginal improvement in the maintenance of $\mathrm{Fv} / \mathrm{Fm}$ at all temperatures, although the effect was least noticeable at 5,10 , and $15^{\circ} \mathrm{C}$.

\section{Discussion}

The reduction in softening rate of 'Redchief Delicious' apple fruit by $1-\mathrm{MCP}$ was consistent with results from other studies (Dauny and Joyce, 2002; DeEll et al., 2002; Fan et al., 1999a; Mir et al., 2001; Watkins et al., 2000), demonstrating the inhibitory influence of 1-MCP on apple ripening. The 16-h exposure used in the current study should have been sufficient to obtain the full response for the concentrations applied. Dauny and Joyce (2002) and DeEll et al. (2002) obtained no increase in responses to 1-MCP for exposure durations greater than $6 \mathrm{~h}$ for 1.0 and $0.6 \mu \mathrm{L} \cdot \mathrm{L}^{-1}$ $1-\mathrm{MCP}$, respectively. Our data agree with those of one previous study (Fan et al., 1999a) in which dose-response experiments were 


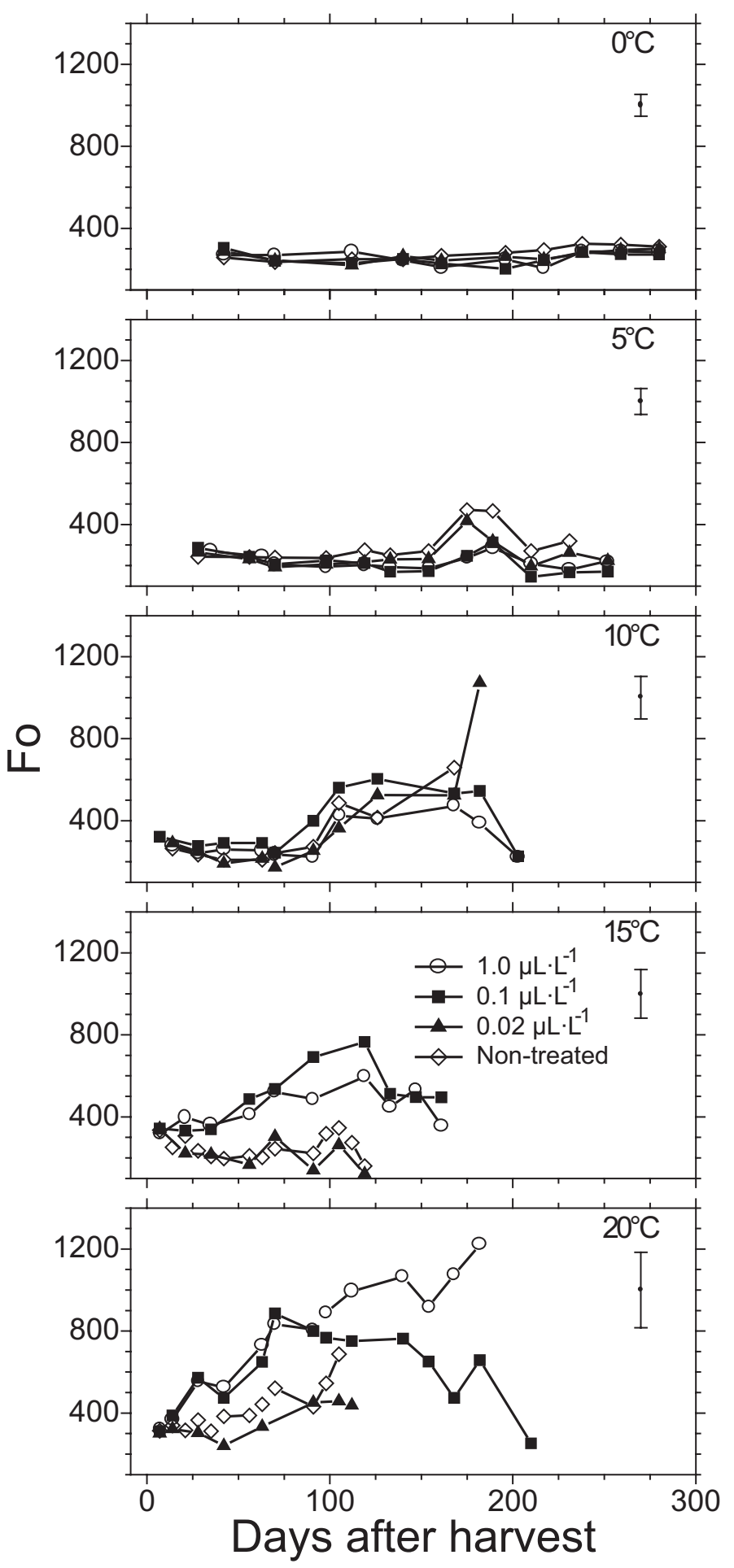

Fig. 3. Minimal chlorophyll fluorescence (Fo) of 'Redchief Delicious' apple fruit after storage in air at $20,15,10,5$, or $0^{\circ} \mathrm{C}$ with and without weekly exposures to $1.00,0.10$, and $0.02 \mu \mathrm{L} \cdot \mathrm{L}^{-1} 1$-MCP. Fluorescence measurements were made after holding fruit for an additional $24 \mathrm{~h}$ at $20{ }^{\circ} \mathrm{C}$. Bars are \pm the average SD for all samples of the given temperature; $\mathrm{n}=10$ fruit, five from each of two replicates.

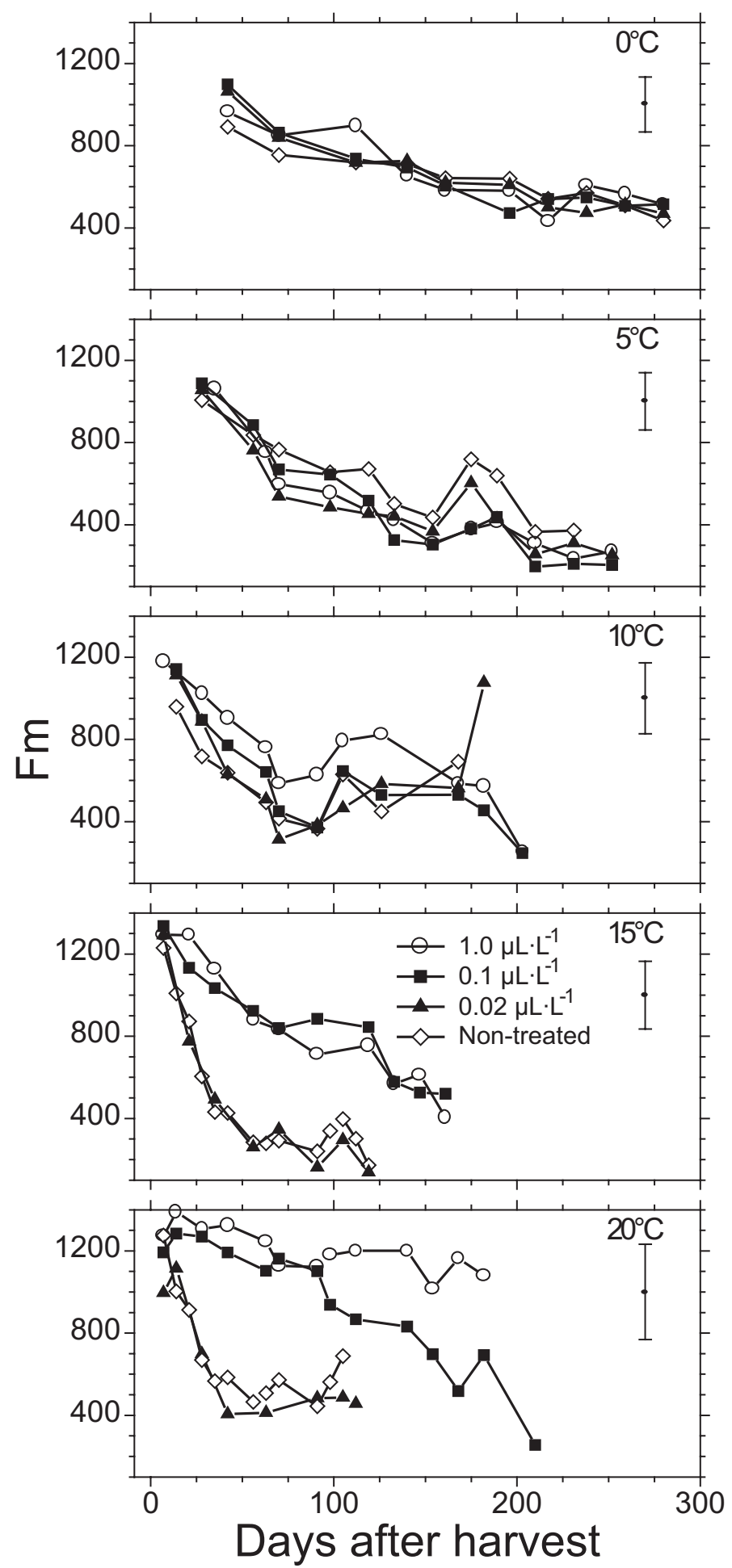

Fig. 4. Maximal chlorophyll fluorescence (Fm) of 'Redchief Delicious' apple fruit after storage in air at $20,15,10,5$, or $0{ }^{\circ} \mathrm{C}$ with and without weekly exposures to $1.00,0.10$, and $0.02 \mu \mathrm{L} \cdot \mathrm{L}^{-1} 1$-MCP. Fluorescence measurements were made after holding fruit for an additional $24 \mathrm{~h}$ at $20^{\circ} \mathrm{C}$. Bars are \pm the average SD for all samples of the given temperature; $n=10$ fruit, five from each of two replicates. 


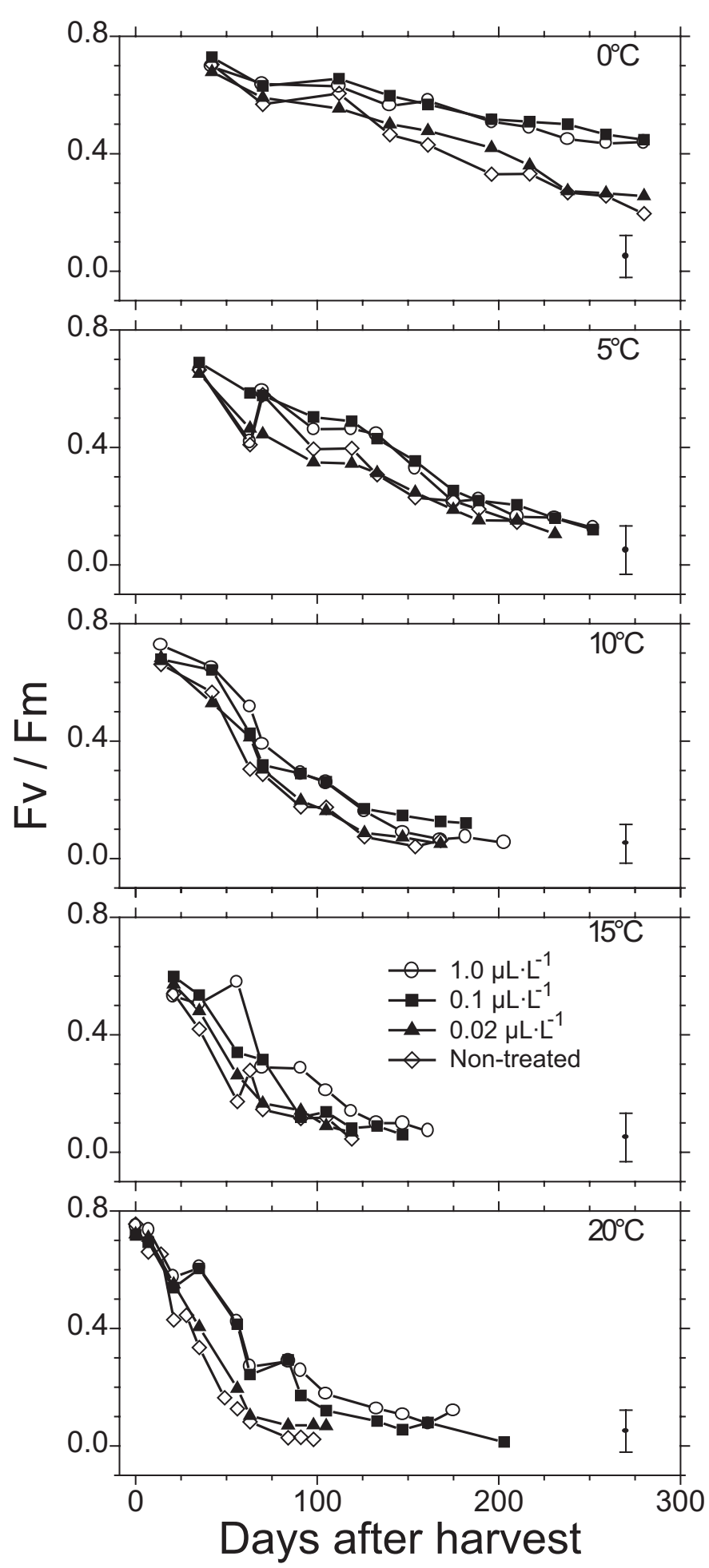

Fig. 5. Photochemical efficiency as measured by chlorophyll fluorescence (Fv/ Fm) of 'Redchief Delicious' apple fruit after storage in air at 20, 15, 10, 5, or 0 ${ }^{\circ} \mathrm{C}$ with and without weekly exposures to $1.00,0.10$, and $0.02 \mu \mathrm{L} \cdot \mathrm{L}^{-1} 1-\mathrm{MCP}$. Fluorescence measurements were made after holding fruit for an additional 24 $\mathrm{h}$ at $20^{\circ} \mathrm{C}$. Bars are \pm the average sD for all samples of the given temperature; $\mathrm{n}=10$ fruit, five from each of two replicates.

performed at 20 to $24^{\circ} \mathrm{C}$ and a second study (Dauny and Joyce, 2002) in which the application temperature of a dose-response experiment was either 0 or $20^{\circ} \mathrm{C}$, in that the response to $1-\mathrm{MCP}$ was saturated effectively by $1.0 \mu \mathrm{L} \cdot \mathrm{L}^{-1}$. Similarly, we found that the response to $0.1 \mu \mathrm{L} \cdot \mathrm{L}^{-1} 1-\mathrm{MCP}$ was nearly as effective as 1.0 $\mu \mathrm{L} \cdot \mathrm{L}^{-1}$. In the present study, there were no obvious differences in the effectiveness of the two highest concentrations for the first $100 \mathrm{~d}$ of the study for all temperatures. However, after this time, it was evident the efficacy of $0.1 \mu \mathrm{L} \cdot \mathrm{L}^{-1}$ in preventing firmness loss and, to some extent, chlorophyll fluorescence changes, waned in a temperature-dependent manner. By the conclusion of the studies at the various temperatures, it was evident that, as storage temperature increased, the effectiveness of the $0.1 \mu \mathrm{L} \cdot \mathrm{L}^{-1} 1-\mathrm{MCP}$ treatment declined relative to the $1.0 \mu \mathrm{L} \cdot \mathrm{L}^{-1}$ treatment. The loss in efficacy of the $0.1 \mu \mathrm{L} \cdot \mathrm{L}^{-1}$ treatment may be due to an inability of the low level of 1-MCP to saturate binding sites such that the fruit continued to 'sense' available ethylene, enabling ripening to proceed slowly.

Blankenship and Dole (2003) noted that 1-MCP is thought by some to bind the ethylene binding site(s) in an essentially irreversible manner, although they further assert that there are little direct supporting data. If binding is irreversible in apple, then one would expect that some sites not occupied following the first exposure to nonsaturating levels of 1-MCP (e.g., 0.1 $\mu \mathrm{L} \cdot \mathrm{L}^{-1} 1-\mathrm{MCP}$ and less) very likely would be bound by $1-\mathrm{MCP}$ during subsequent exposures. Thus, in an irreversible binding scenario, the efficacy of $0.1 \mu \mathrm{L} \cdot \mathrm{L}^{-1}$ should have increased with time as long as the turnover rate of the ethylene receptors resulted in no net gain in receptors over time. Given that a single exposure of $0.7 \mu \mathrm{L} \cdot \mathrm{L}^{-1} 1-\mathrm{MCP}$ prevented firmness loss in 'Redchief Delicious' for over $30 \mathrm{~d}$ at $20^{\circ} \mathrm{C}$ (Mir et al., 2001), binding site turnover in apple would be expected to be quite low such that some of the binding sites are retained for as long as 4 weeks at high temperatures, and likely longer at low temperatures. Since the efficacy of weekly $0.1 \mu \mathrm{L} \cdot \mathrm{L}^{-1} 1$-MCP treatments declined, it is more likely, therefore, that $1-\mathrm{MCP}$ does not bind irreversibly, but rather slowly dissociates from the ethylene binding sites (Serek and Sisler, 2001; Sisler et al., 1996; Sisler and Serek, 1999). This view is consistent with previous measures of 1-MCP and ethylene dissociation constants (Sisler and Serek, 1997) and further supports the suggestion by Watkins et al. (2000) that high levels of ethylene found in 'McIntosh' apple fruit may compete actively with 1-MCP.

Temperature had a marked influence on the rate of fruit softening, which increased $\approx 9$-fold as temperature increased from 0 to $20{ }^{\circ} \mathrm{C}$. The relatively linear increase in the rate of softening with increasing temperature suggests that softening processes in apple are not affected by temperature in the same manner as metabolism as judged by respiratory rate, which increases with temperature in a curvilinear manner (Hardenburg et al., 1986 and citations therein).

The interaction between temperature and 1-MCP efficacy in reducing firmness loss appeared to be somewhat complex. The greatest rate of softening of 'Redchief Delicious' apple fruit treated weekly with $1 \mu \mathrm{L} \cdot \mathrm{L}^{-1} 1-\mathrm{MCP}$ occurred at $10^{\circ} \mathrm{C}$. This was consistent with the findings of Mir et al. (2001) using multiple exposures to $0.7 \mu \mathrm{L} \cdot \mathrm{L}^{-1} 1-\mathrm{MCP}$. They showed that the storage life of 1-MCP-treated 'Redchief Delicious' apple fruit, when measured in terms of firmness retention, was minimized at $10^{\circ} \mathrm{C}$ and increased as temperature increased and declined. However, the slight increase in firmness at $0^{\circ} \mathrm{C}$ for fruit treated with 0.1 and $1.0 \mu \mathrm{L} \cdot \mathrm{L}^{-1} 1-\mathrm{MCP}$ was not found previously by Mir et al. (2001). The slight increase in firmness at $0{ }^{\circ} \mathrm{C}$ may be due to moisture loss, although no shriveling was evident; alternatively, 1-MCP may alter cell wall metabolism such that synthetic reactions can, in some instances, marginally outpace catabolic reactions at low temperature. 
The chlorophyll fluorescence data (Fo, Fm, and Fv/Fm) for 0.1 and $1.0 \mu \mathrm{L} \cdot \mathrm{L}^{-1} 1-\mathrm{MCP}$ treatments are consistent with those published previously for repeat applications of $0.7 \mu \mathrm{L} \cdot \mathrm{L}^{-1} 1-\mathrm{MCP}(\mathrm{Mir}$ et al., 2001) as well as nontreated (Mir et al., 2001) and air-stored fruit (Song et al., 1997). The similarity in the dose-dependency of changes in firmness with that of Fo, Fm, and Fv/Fm in the current study suggests that textural and chloroplastic responses have a similar dependence on the concentration of 1-MCP. However, the magnitude of the influence of 1-MCP on firmness retention was not reflected in the magnitude of the effect on Fv/Fm. The marked time-dependent decline in $\mathrm{Fv} / \mathrm{Fm}$ demonstrated that chloroplast function was not protected appreciably by 1-MCP treatment, suggesting ethylene has a real, but minor, role to play in the loss in chloroplast function during storage. The temperature dependence of the influence of $1.0 \mu \mathrm{L} \cdot \mathrm{L}^{-1} 1-\mathrm{MCP}$ on Fo and Fm in stored apple was similar to that reported by Mir et al. (2001). The data suggest that at high temperatures, ethylene limits the time-dependent decline in Fm and enhances the increase in Fo, but at low temperature, changes in these parameters are governed by a factor other than ethylene.

Our studies confirmed the earlier published results (Mir et al., 2001) that $1 \mu \mathrm{L} \cdot \mathrm{L}^{-1}$ application to 'Redchief Delicious' apples once per week was highly effective at preserving fruit firmness at higher temperatures. Under special circumstances (e.g., lack of access to refrigeration and/or modified-atmosphere storage), 1-MCP may be helpful in maintaining apple fruit firmness at elevated temperatures. However, while firmness is one of the most important quality attributes for apples (Arthey, 1975; Liu and King, 1978), storage at elevated temperatures likely would lead to losses in other quality attributes. For instance, the high rates of fungal decay found in the current study at higher storage temperatures, while lower for 1-MCP-treated fruit, would be expected to severely limit storage of apple at nonoptimal storage temperatures.

The dose-response for multiple doses of 1-MCP appears to be very similar to that for single doses. The lack of a difference between the dose-response of single and repeated doses suggests that binding is not irreversible, or else subsequent doses of subsaturating concentrations of 1-MCP in the multiple dose system would have improved the response of fruit by binding to a portion of the remaining unbound ethylene binding sites. One would anticipate, therefore, that a continuous dosage at concentrations below those that saturate the response would behave similarly to sub-saturating repeated and single doses and result in incomplete inhibition of ethylene action.

There appeared to be no shift in dose-response with temperature. A previous study documenting the slight increase in the exposure duration required at lower temperatures (DeEll et al., 2002) may describe the influence of temperature on the diffusion of 1-MCP into and through the fruit, rather than a shift in tissue responsiveness. The relative insensitivity of the 1-MCP dose-response to temperature suggests that binding is influenced little by temperature and may be characterized by a low apparent enthalpy. The influence of temperature on the dose-response of plant material for ethylene has, to our knowledge, not yet been reported, nor has the enthalpy of ethylene binding been published.

\section{Literature Cited}

Abdi, N., W.B. McGlasson, P. Holford, M. Williams, and Y. Mizrahi. 1998. Responses of climacteric and suppressed-climacteric plums to treatment with propylene and 1-methylcyclopropene. Postharvest Biol. Technol. 14:29-39.
Arthey, V.D. 1975. Quality of horticultural products. Wiley, New York. Blankenship, S.M. and J.M. Dole. 2003. 1-Methylcyclopropene: A review. Postharvest Biol. Technol. 28:1-25.

Cameron, A.C. and M.S. Reid. 2001.1-MCP blocks ethylene-induced petal abscission of Pelargonium peltatum but the effect is transient. Postharvest Biol. Technol. 22:169-177.

Dauny, P. and D. Joyce. 2002. 1-MCP improves storability of 'Queen Cox' and 'Bramley' apple fruit. HortScience. 37:1082-1085.

DeEll, J.R., D.P. Murr, M.D. Porteous, and H.P.V. Rupasinghe. 2002. Influence of temperature and duration of 1-methylcyclopropene (1-MCP) treatment on apple quality. Postharvest Biol. Technol. 24:349-353.

Environmental Protection Agency. 2002. 1-Methylcyclopropene: Exemption from the requirement of a tolerance. Federal Register 67:48796-48800.

Fan, X., S.M. Blankenship, and J.P. Mattheis. 1999a. 1-Methylcyclopropene inhibits apple ripening. J. Amer. Soc. Hort. Sci. 124:690-695.

Fan, X., J.P. Mattheis, and S.M. Blankenship. 1999b. Development of apple superficial scald, soft scald, core flush, and greasiness is reduced by MCP. J. Agr. Food Chem. 47:3063-3068.

Golding, J.B., D. Shearer, S.G. Wyllie, and W.B. McGlasson. 1998. Application of 1-MCP and propylene to identify ethylene-dependent ripening processes in mature banana fruit. Postharvest Biol. Technol. 14:127-132.

Hardenburg, R.E., A.E. Watada, and C.Y. Wang. 1986. The commercial storage of fruits, vegetables, and florist and nursery stocks. USDA Hdbk. 66, USDA-ARS.

Ku, V.V.V. and R.B.H. Wills. 1999. Effect of 1-methylcyclopropene on the storage life of broccoli. Postharvest Biol. Technol. 17:127-132.

Liu, F.W. and M.M. King. 1978. Consumer evaluations of 'McIntosh' apple firmness. HortScience 13:162-163.

Lurie, S., C. Pre-Aymard, U. Ravid, O. Larkov, and E. Fallik. 2002. Effect of 1-methylcyclopropene on volatile emission and aroma in cv. Anna apples. J. Agr. Food Chem. 50:4251-4256.

Mir, N. and R.M. Beaudry. 2001. Use of 1-MCP to reduce the requirement for refrigeration in the storage of apple fruit. Acta Hort. 553:577-580.

Mir, N., M. Canoles, R. Beaudry, E. Baldwin, and C. Mehla. 2003. Inhibition of tomato ripening by 1 -methylcyclopropene. J. Amer. Soc. Hort. Sci. 129:112-120.

Mir, N.A, E. Curell, N. Khan, M. Whitaker, and R.M. Beaudry. 2001. Harvest maturity, storage temperature, and 1-MCPapplication frequency alter firmness retention and chlorophyll fluorescence of 'Redchief Delicious' apple fruit. J. Amer. Soc. Hort. Sci. 125:618-624.

Porat, R., B. Weiss, L. Cohen, A. Daus, R. Goren, and S. Droby. 1999. Effects of ethylene and 1-methylcyclopropene on the postharvest qualities of 'Shamouti' oranges. Postharvest Biol. Technol. 15:155-163.

Rupasinghe, H.P.V., D.P. Murr, G. Paliyath, and L. Skog. 2000. Inhibitory effect of 1-MCP on ripening and superficial scald development in 'McIntosh' and 'Delicious' apples. J. Hort. Sci. Biotechnol. 75:271-276.

Serek, M. and E.C. Sisler. 2001. Efficacy of inhibitors of ethylene binding in improvement of the postharvest characteristics of potted flowering plants. Postharvest Biol. Technol 23:161-166.

Serek, M., E.C. Sisler, and M.S. Reid. 1994. A volatile ethylene inhibitor improves the postharvest life of potted roses. J. Amer. Soc. Hort. Sci. 119:572-577.

Sisler, E. and S. Blankenship. 1996. Method of counteracting an ethylene response in plants. U.S. Patent No. 5,518,988 (May 21, 1996). U.S. Patent and Trademark Office, Washington D.C.

Sisler, E.C., E. Dupille, and M. Serek. 1996. Effect of 1-methylcyclopropene and methylenecyclopropane on ethylene binding and ethylene action on cut carnations. Plant Growth Regulat. 18:79-86.

Sisler, E.C. and M. Serek. 1997. Inhibitors of ethylene responses in plants at the receptor level: recent developments. Physiol. Plant. 100:577-582.

Sisler, E.C. and M. Serek. 1999. Compounds controlling the ethylene receptor. Bot. Bul. Acad. Sinica 40:1-7.

Song, J., W. Deng, R.M. Beaudry, and P.R. Armstrong. 1997. Changes in chlorophyll fluorescence of apple fruit during maturation, ripening and senescence. HortScience 32:891-896.

Watkins, C.B., J.F. Nock, and B.D. Whitaker. 2000. Responses of early, mid and late season apple cultivars to postharvest application of 1methylcyclopropene (1-MCP) under air and controlled atmosphere storage conditions. Postharvest Biol. Technol. 19:17-23. 